Plants collected June 14 at Sachs Harbour were: Cassiope tetragona, Stellaria laeta, Papaver radicatum, Arenaria rubella, Dryas integrifolia, Oxytropis arctica, Salix arctica, Agropyron latiglume, Trisetum spicatum, Poa alpigeua and Poa glauca.

In addition to these, I collected the following at Fish Lakes: Juncus biglumis, Carex membranacea, Salix richardsonii, Pedicularis lanata, Luzula confusa, Eriophorum callibrix, and Festuca callibrix. While at "Sand Creek" a few additional ones were added, Salix pseudopolaris and Kobresia bellardi. (Identifications were made by Dr. A. E. Porsild.)

A number of insects and spiders were identified by J. E. H. Martin, M. R. MacKay, H. E. Milliron, J. R. Vockeroth, J. G. Chillcott and W. J. Brown. The insects and spiders were: Araneida sp., Bombus sylvicola, Scatophaga multisetosa, Phalacrodira sp., Rymosia sp., Fucellia pictipennis, Hylemya sp., and Amara glacialis.

\section{Acknowledgments}

I wish to thank the above men who helped identify the plants and insects and spiders. I also wish to thank W. Earl Godfrey, National Museum of Canada, for all the help he gave me, as well as the Royal Canadian Mounted Police Officers, James Quinn and John Naeve at Sachs Harbour, and the men at the Federal Department of Transport headquarters for allowing me to use their headquarters facilities when I was in Sachs Harbour. I wish also to thank the Kuptana family, Robert, William and Roger, for transporting me by dog team from place to place.

\section{LITERATURE CITED}

Baker, B. W., and L. H. Walkinshaw. 1946. Bird notes from Fawcett, Aiberta. Can. Field-Nat., $60: 5-10$.

Manning, T. H., E. O. Höhn, and A. H. MacPherson. 1956. The birds of Banks Island. Nat. Mus. Canada, Bull. No. 143. Min. of N. Affairs and Nat. Resources, Ottawa. iv. + $144 \mathrm{p}$.

\title{
BLACK-HEADED GROSBEAK BREEDING RECORD FOR SOUTH-CENTRAL SASKATCHEWAN
}

\author{
by Robert D. Symons, Silton, and Robert W. Nero, Regina
}

The Black-headed Grosbeak (Pheucticus melanoleucus) has been known to breed in Canada in southern British Columbia, southern Alberta, and southern Saskatchewan (A.O.U., 1957). Salt and Wilk (1958) list it as a scarce summer resident for extreme southeastern Alberta. Godfrey (1950) reports it breeding in the Cypress Hills region of Saskatchewan, but it has not been known to nest elsewhere in this province. Observations which indicate a breeding record for south-central Saskatchewan on Last Mountain Lake, approximately 30 miles northwest of Regina, are therefore of considerable interest.

Symons observed and kept notes on a pair of Black-headed Grosbeaks at Pelican Point, Last Mountain Lake, from May 13 to October 13, 1962. Although a nest was not found, the adults were seen in the same vicinity during each month of this period, and fledged young were seen on July 27.

Symons recently prepared the following account of his observations, based on notes recorded at the time:

May 13: I first observed a pair of Black-headed Grosbeaks perched at a low level in a group of cultivated Russian poplars on a cottage lot. The trees were not yet in leaf. The early morning sun was not yet high, so the birds were not in shade on their undersides. This, combined with the colourless landscape of the pre-leafage period, made the birds appear as strongly and brilliantly coloured as orioles, for which indeed I at first mistook them. However, they lacked the dash and restlessness of orioles, and besides, their outline appeared more chunky. I approached to within 30 yards and recognized them as Black-headed Grosbeaks, having observed a male of 
this species for some time during 1940 at Frank Nuttall's ranch in the Cypress Hills.

The birds were quite tame and I was able to make positive identification bath by naked eye and with field glasses. The male was certainly colourful in the strong sunlight. Presently this bird uttered a "Klip" note, resembling the short alarm note of the Rose-breasted Grosibeak. They finally moved from cottage to cottage, perching briefly on suitable trees or shrubs, but this movement was desultory, and unhurried. They now flitted to the shoreline below and began to pick about on the ground, until the male mounted a dry sweet clover stalk and sang in the manner of a Rosebreasted Grosbeak. Immediately the female flew landward, and with the male in close pursuit, they both disappeared over the hill towards the east side. No mating occurred in my presence. The weather was cool but sunny.

May 19: The trees were now leafing out. I took a walk in the heavier woods on the east side in hopes of seeing these birds again. On the way a Rose-breasted Grosbeak "Klipped" at me, and then flew north towards the uplands. Further on I heard the note again. It took some minutes to locate this bird, but I was not disappointed as it was my Black-headed friend. Again he sang, this time from a tall Saskatoon bush and as before the female flew rapidly away, this time from a heavy patch of chokecherry which dominates the edge of this woodland. She flew straight east, parallel to the lake, and again the male immediately followed. No mating was observed. A careful search of the not yet fully leafed cherry patch revealed nothing in the way of a nest, either constructed or under construction. The day was hot and the hillside redolent with the cloying odour of cherry blossom.

May 25: I again located a pair of these birds, presumably the same pair I had seen. This was among rolling semi-wooded hills about half a mile east of the point in John Day's pasture. This time they were harder to approach; and the leaf cover being dense, they were also harder to sight. I finally got a good view of the male while he was singing (which was at more or less regular intervals). The female was again down in the shrubbery but I did not observe her till she flew. This time the male paused to sing once more before he followed her. Again, I saw no actual mating.

June 7: On passing by the clump of chokecherry already mentioned, I heard the male singing, and saw him in a tallish elm in the rear of the cherries. This patch of chokecherry is quite extensive, being upward of 150 yards long by 30 yards wide, with heavy woods behind it and open hillside in front. I felt sure that these birds were nesting here, as I have commonly found Rose-breasteds making use of similar situations, preferring the taller bushes bordering on woods to the woods themselves. I again searched diligently but found nothing, nor did I observe the female. This patch of brush can only be searched by crawling on hands and knees. It is impossible to move in an upright position, and one is further impeded by the fact that "escaped" wild cucumber vines completely fill up any interstices in the close-laced boughs and add to the gloom caused by the heavy leafage. I did, however, stumble upon a nest with eggs of a Rufous-sided Towhee, and as I searched I could hear alternate "Klips" from the grosbeak and "T'whee's?" from the towhee. (It was in this same tangle that on the following year I was to find the nest of a Yellowbreasted Chat. On that occasion I had to work the area inch by inch and it took two full days, while all the time the Chat jeered at me.) After a couple of hours searching for the nest of the grosbeak I desisted for fear of driving the birds entirely away.

July 27: On this date I observed two fledgling grosbeaks being fed by a female. This was in a lilac clump in a cottage garden directly below and about 200 yards distant from the chokecherry thicket. I believed them at once to be the same birds since the female, so like a Rose-breasted Grosbeak, lacked the geveral streakiness, showed the washed-sut buffy rump, and was without the light streak above the eye which is characteristic of the Rose-breasted. The young birds still carried "ear tufts" of down, and their wing and tail feathers were 
about half-grown. Not wishing to disturb the birds unduly I did not search the lilacs for a nest. The cottage owners had been coming out at intervals from the city, and although the young birds were in that "floppy" stage which indicates a nest at no great distance, I still believe that the actual site of the nest must have been on the seclusion of the hillside. (A subsequent search of the lilacs drew a blank.) Then the male arrived and perched in full view. He had brought no food, but remained a mere onlooker until the female dashed towards the lakeshore, when he at once gave chase. It would seem that he was more interested in a second mating than in the young birds.

August 14: On the west side of the point, I saw the male perched on the top of a green sweet clover. At my approach he moved north about 20 feet. Something fluttered close to me which proved to be a juvenile grosbeak. It was joined by another. Their wing and tail feathers were now well grown, and no sign of down was left. I saw nothing of the female, and wondered if she had a second nest.

August 15: On this date both the male and female were seen with one young in the same place. Both juveniles may well have been males as their plumage was more ruddy than the female and both showed a yellow wash on the underwings. The female also showed that "worn" appearance in her plumage which is often noticeable in a bird which has raised a family; the end of the tail feathers a little "scruffy" looking, etc. I did not see either parent feed the young, although the juveniles fluttered their wings in anticipation from time to time.

September 15: Both juveniles were seen in the same vicinity. I located the male about a quarter of a mile away.

October 4: This day the two juveniles, now in full fall plumage, were seen in rose bushes north of my cottage. They fed together, on the ground, but from time to time mounted the rose canes.

October 13: Both juveniles and the female fed most of the day around the Russian poplars first mentioned. They were in company with three migrating White-throated Sparrows and one Junco. They spent most of the time on the ground, searching among the fallen yellow leaves, and also among some half-dried sweet-peas growing on a trellis. I could not be sure whether or not they opened some pods. They did pick out a few sunflower seeds from a ripe head which had been thrown on a rubbish-heap.

This was the last time I saw these birds. If the female had nested a second time her nest was probably destroyed, as I am certain I had seen the same two young each time. In any case, August would have been late for nesting.

I should mention that the plumage colour of the Black-headed Grosbeak is (from an artist's appraisal) richly cinnamon, rather than orange. The pink - tinted artist's colour called Naples yellow (in bulk rather than thinly spread) would come near it. It is warm on rump and sides of breast, more yellow in centre of breast on the male. Streaking, if noticeable at all, is faint. If one substituted cinnamon for the white rump and flanks, yellowish on breast and divided the black head from the rest of the plumage on a Rose-breasted Grosbeak, that would be the Black-headed Grosbeak. The wing pattern is the same in both birds.

Incidentally, in 1962 I only saw the one Rose-breasted male certainly identified in that vicinity, although in 1963 and 1964 I saw several.

Pelican Point is situated on the east side of Last Mountain Lake, about eight miles west of Silton, or 49 miles (by road) northwest of Regina. The point itself thrusts out from the prairie level, shelving sharply to the southwest and continuing at near water-level in a sandspit which extends for 250 yards into the lake. It forms the inner angle between the northern and southern arms of the lake. The hillsides are generally grassy, spear grass forming the chief species, but this is interspersed with pasture sage and brittle prickly pear as well as pincushion cactus. Elsewhere the flora is typical dry prairie hillsides, i.e.: beard's tongue, wild parsley, buffalo beans, pasque flowers, etc., with Nuttall's Atriplex conspic- 


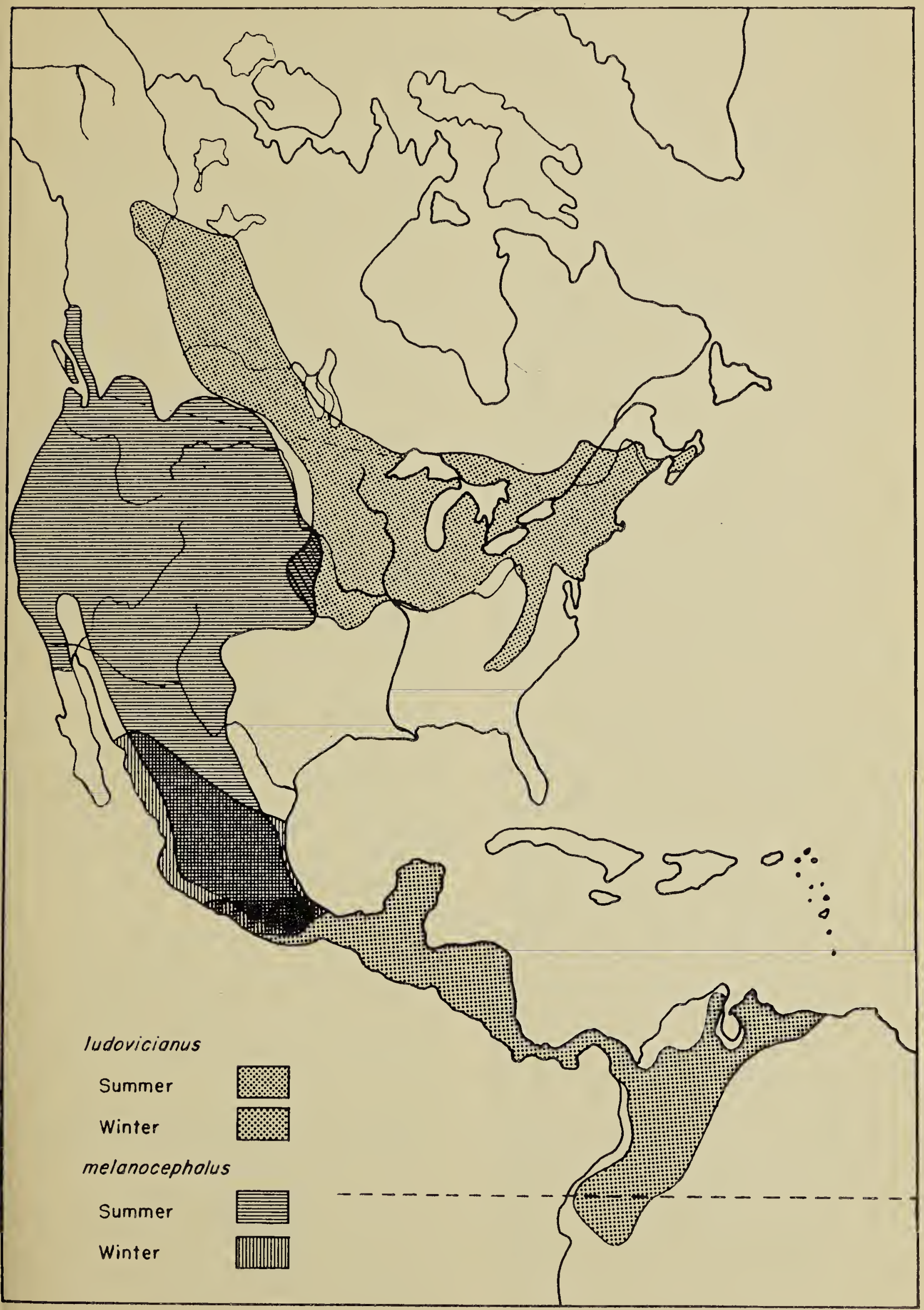

Figure 1. Approximate breeding and winter ranges of the two North American Pheucticus. Data from Dr. E. M. Reilly, unpublished. [West, 1962] 
uous in the more eroded spots. Swales admit of "islands" of snowberry and luxuriant thickets of wild rose. The numerous coulees are wooded with Manitoba maple, ash and elm, usually heavily bordered with tangles of chokecherry and Saskatoon brush. On the east side of the point the tree growth is more extensive and not entirely confined to the coulees themselves. No aspen occurs below the prairie level. The lake shore is rocky with sandy patches, which carry a heavy growth of self-sown sweet clover. This, while unsightly, provides good cover for ducklings; while passerine birds crowd into it during hot weather, after their young are fledged. Prevailing strong winds come across the lake from the west and northwest. This accounts for heavier tree growth and greater abundance of birds on the east side of the point. There are upwards of 40 summer cottages, mostly on the south and west sides. There is, therefore, considerable activity at week-ends, and birds are much disturbed by children, dogs and cats.

This record appears to be a case of extra-limital breeding rather than an extension of the range of the Blackheaded Grosbeak, for the nearest known breeding localities are in the Cypress Hills to the west-southwest (Godfrey, 1950) at Glasgow, Montana, to the southwest, and Charlson, North Dakota, to the southeast (A.O.U., 1957), all roughly 200 miles away. (Glasgow is the closest locality.) This species was not found in the South Saskatchewan River valley north and east of Swift Current during recent surveys by the Saskatchewan Museum of Natural History (R. D. Carson, personal communication, 1965), although there is extensive wooded habitat on islands and in coulees of that section of the valley. It was not listed for the nearby Elbow and Tullis regions (Roy, 1964). The possibility of other extra-limital breeding is suggested by scattered records of its occurrence as far north as Nipawin (Houston and Street, 1959), and its appearance far to the east in Manitoba (see accompanying report in this issue of the Blue Jay).

The map presented by West (1962) (fig. 1) shows a fairly close contact between the ranges of the Blackheaded Grosbeak and the more east- erly Rose-breasted Grosbeak (Pheucticus ludovicianus) in southern Saskatchewan, although, as West points out, the "aspen forest north of the Canadian prairies delimits grosbeak distribution in the area, with the exception of the river valleys of southern Manitoba, Saskatchewan, and Alberta." West states that both grosbeaks have been found breeding in the Cypress Hills in Saskatchewan, information which he attributes to Godfrey (1950). This must, however, be an error, since Godfrey reports only a few sight records for the Rose-breasted Grosbeak in that region. The gap between Black-headed Grosbeak populations in the Cypress Hills and Rose-breasted Grosbeak populations to the east may be more than 200 miles. The nearest likely breeding Rose-breasted Grosbeaks may be found in the wooded coulees of the Qu'Appelle River valley, about 20 miles north-northwest of Regina (personal observations, R. W. Nero, 1964). It is of interest to note that this is only about 15 miles from Pelican Point. The zone of contact between these two forms in Saskatchewan must be slight. In the southern Plains, where there is a considerable overlap of their ranges, these two grosbeaks hybridize freely (West, 1962). West believes that there has been an increase in range overlap during this century, brought about by the availability and increase in wooded habitat in river valleys extending across the grassland of the Great Plains. This pattern is less clear in Saskatchewan.

\section{LITERATURE CITED}

A.O.U. Committee. 1957. Checklist of North American birds. Fifth ed. Baltimore. 691 p.

Godfrey, W. E. 1950. Birds of the Cypress Hills and Flotten Lake regions, Saskatchewan. Natl. Mus, Can., Bull. 120. Ottawa. $96 \mathrm{p}$.

Houston, C. S., and M. G. Street. 1959. The birds of the Saskatchewan River, Carlton to Cumberland. Sask. Natural History Soc., Spec. Pub. No. 2, Regina. 205 p.

Roy, J. F. 1964. An introduction to the birds of the Elbow. Sask. Natural History Soc., Regina. mimeo., $33 \mathrm{p}$.

Salt, W. R., and A. L. Wilk. 1958. The birds of Alberta. The Queen's Printer,'Edmonton. $511 \mathrm{p}$.

West, D. A. 1962. Hybridization in grosbeaks (Pheucticus) of the Great Plains. Auk, 79: 399-424. 